\title{
COVID-19 pandemisi sürecinde yaşlıya yönelik ayrımcı uygulamalar ve yaşlı bireyler cephesinde durum değerlendirilmesi
}

\author{
Discriminatory practices towards the elderly during the COVID-19 pandemic and \\ assessment of the situation on the elderly people
}

\author{
Burcu Demir Aliye Mandıracıoğlu \\ Ege Üniversitesi Tıp Fakültesi Halk Sağlığı Anabilim Dalı, İzmir, Türkiye
}

\section{Öz}

COVID-19'un ortaya çıkışı, dünyada karışık, sürekli gelişen ve değişen bir durum ortaya çıkararak her yaştan insanı etkilemeye devam etmektedir. Ancak virüse bağlı ciddi hastalık gelişimi ve ölme riski yaşla birlikte artar. Bu durum, COVID-19 pandemisi sürecinde altta yatan yaşa dayalı ayrımcı tutumları ortaya çıkaran veya teşvik eden çok sayıda sorunlu politika önerileri ve yorumlarına yol açmaktadır. Yaşlıları homojen bir şekilde 'kırılgan' ve 'savunmasız' olarak etiketlendiren bu yaklaşım, kitlelerin yaş temelindeki ayrımcı tutumlarını körükleyerek pandemiye paralel bir yaşlı ayrımcılığı salgınının patlak vermesine sebep olmuştur. Virüsle mücadele esnasında sağlık bakımında ve sokağa çıkış kısıtlaması uygulamalarında yaş temelli kararların alınması, medyada ve sağlık yetkilileri açıklamalarında 'yaşlı' vurgusunun tekrarlaması, sosyal medyada yaşı bireylere yönelik ötekileştirme/siber zorbalık/stigmatizasyonun artışı tüm toplumlarda yaşanan problemlerdir. Yaşlının esenliğine, özerkliğine ve yaşam hakkına zarar veren bu yaklaşımların yerleşip kurumsallaşması yaşılıarın toplumdan dışlanmasıyla sonuçlanacaktır. Ayrıca genç ve yaşlı arasındaki bölünme, mevcut pandemi bağlamında yaşlılık ve yaşlanmayla ilgili olumsuz mesajları içselleştiren gençlerin yaşlanma sürecini olumsuz etkileyebilir.

Anahtar Sözcükler: Yaşlanma, yaşı ayrımcılığı, covid-19, pandemi.

\begin{abstract}
The emergence of COVID-19 has created a complex, ever-evolving and changing situation in the world that affected people of all ages, in different ways. The risk of developing severe illness from the virus and of dying from it increases with age. This statement has led to numerous highly problematic policy suggestions and comments revealing underlying ageist attitudes and promoting age discrimination. This approach, which labels the elderly as "frail" and "vulnerable" in a homogeneous way, has fueled the age-based discriminatory attitudes of the masses, causing an epidemic of age discrimination parallel to the pandemic. Age-based decisions in health care and curfews during the fight against the virus, the repetition of the 'old' emphasis in the media and health officials' statements, the increase of marginalization / cyberbullying / stigmatization towards elderly individuals on social media are the problems experienced in all societies. The establishment and institutionalization of these approaches that harm the well-being, autonomy and right to life of the elderly will result in the exclusion of the elderly from society. In addition, the division between young and old can negatively affect the aging process of young people, who internalize negative messages about old age and aging in the context of the current pandemic.
\end{abstract}

Keywords: Aging, ageism, COVID-19, pandemics.

\footnotetext{
Sorumlu yazar: Burcu Demir

Ege Üniversitesi Tıp Fakültesi Halk Sağlığı Anabilim Dalı, İzmir, Türkiye

E-posta: burcu8894@gmail.com

Başvuru tarihi: 27.04.2021 Kabul tarihi: 20.05.2021
} 


\section{GíRiş}

\section{Yaşlı ayrımcılığı nedenleri ve sonuçları}

Yaşlanmayı 'olumlu' bir deneyim olarak değerlendiren, yaşlıların topluma katkılarını önemseyen ve yaşlanmayı bir yükten çok bir fırsat olarak değerlendiren bir vizyonla modern toplumların şekillendirilmesi ihtiyacı her geçen gün artmaktadır. Dünya Sağıık Örgütü (DSÖ) öncülügünde 1980'li yıllardan itibaren 'sağlıklı', 'başarılı', 'aktif', 'üretken' gibi yaşlanmanın olumlu yönlerini vurgulayan yeni bir 'paradigma', 'mantra' arayışı küresel düzeyde sürdürülmektedir (1). Yine de "iyi yaşlanmanın" yollarına yönelik sürdürülen çok sayıda deneysel çalışmaya ve halk sağlığını geliştirme stratejilerine rağmen, yaşlanmanın bu olumsuz imgesi canlılığını sürdürmektedir (2). Birleşmiş Milletler (BM), aktif yaşı insanların toplumda daha görünür olduklarında yaşlılara yönelik negatif stereotiplerin azalacağını öngörmektedir (1). Ancak yaşlılara karşı yöneltilmiş 'yaşlı ayrımcılığı' aktif yaşlanmaya yönelik büyük bir tehdit ve önemli bir halk sağlığı problemi olarak geniş çapta kabul edilmektedir (3).

Yaş ayrımcılığı (ageism), bireye sadece kronolojik yaşı nedeniyle veya 'yaşlı algısı' temelinde gösterilen farklı tavır, ön yargı, tutum ve davranışları içerisinde barındıran çok boyutlu bir terimdir (4). Yaş ayrımcılığı, herhangi bir yaş grubunu hedef alabilir ancak mevcut kanıtlar, yaşlıların olumsuz sonuçlarından mağdur olma riskinin daha yüksek olduğunu göstermektedir (5). Illk kez 1969 yılında Robert Butler tarafından tanımlanmış olup ırk ve cinsiyet ayrımcılığı gibi eyleme dönüşebilen bir terim olarak ifade edilmiştir (6). Yaş ayrımcılığı, 1990'lı yıllarda ırk ve cinsiyet ayrımcılığından sonra üçüncü sırada karşılaşılan ayrımcılık türü iken; 2000'li yıllara gelindiğinde küresel düzeyde en yaygın olarak yapılan ayrımcılık olarak kabul edilmektedir (7-9). Yaşlıya yönelik tutumlar nihayetinde bireye özgü olmakla birlikte; kültür, tarih, sosyal yapı ve demografi ile şekillenmektedir ancak bu değişkenlerden bağımsız olarak küresel düzeyde yaygın bir fenomene dönüşmüştür $(10,11)$. DSÖ'nün 2021 tarihli raporunda, küresel olarak her iki kişiden birinin yaşlılara yönelik ayrımcı tutumlara sahip olduğu bildirilmektedir (11).

Marques ve arkadaşları (12) tarafından 2020'de gerçekleştirilen, 1970-2017 yılları arasında çeşitli ülkelerde yayınlanmış çalışmalar üzerinden yaş ayrımcıığının temel belirleyicilerinin değerlendirildiği sistematik derlemede, dış yönelimli ayrımcılık için yaşı insanlarla temasın kalitesi ve yaşlı insanların topluma prezentasyonunun yönü belirleyici iken; özyönelimli yaşlı ayrımcılığı için bireyin sağlık durumu en etkili faktör olarak saptanmıştır. Bireysel düzeyde incelenen yaş, cinsiyet, etnik köken, eğitim durumu, kır/kentte yaşama, dindarlık durumu, sosyo-ekonomik özelliklerin etkileri hakkında kesin ve tutarlı kanıtlar saptanmazken; bireyin kişilik yapısının, 'ölüm korkusu' ve 'yaşlanma anksiyetesinin' daha belirleyici olduğu tespit edilmiştir. Kişiler/ gruplar arası düzeyde, genç ve yaşlı arasındaki temas sıklığından ziyade temasın kalitesi belirleyiciyken organizasyonel/ yapısal düzeyde, çalışmalar yetersiz olmakla birlikte, yaşanılan toplumdaki yaşlıların sayısı ve ekonomik kaynakların durumu belirleyici olmuştur (12).

Yaşı ayrımcılığı dünya çapında kurumlarda, yasalarda ve politikalarda yaygındır. Yapısal düzeyde, sağlık ve sosyal bakım sağlayanlar gibi farklı kurumlarda, işyerinde, medyada ve hukuk sisteminde kendini gösterebilir. Toplumun ve profesyonellerin yaşlılığı algılayışları, bakış açıları ve önyargıları yaşlılara sunulan hizmetlerin kalitesini etkilemektedir (13). Yaşlı bireylerin hastalıkları ve sağlık sorunlarının yaşa bağlı 'beklenen' ve 'normal' bir durum olduğu ön kabulü onların çoğu zaman yeterli ve nitelikli sağlık hizmetine erişimini engellemektedir. Gelişmiş ve gelişmekte olan pek çok ülkedeki akut hastalık odaklı, reaktif ve hastane temelli sağlık sistemlerinde yaşlılar, intiyaç duydukları bütüncül odaklı entegre sosyal ve sağlık hizmetlerine erişememektedir (14).

Bireyin kendisini hedef alan yaşa dayalı olumsuz ön yargı ve tutumlarının, anlamlı olarak bilişsel ve işlevsel performansta azalma ve daha kötü zihinsel sağlık sonuçlarına yol açarken; olumlu tutumları olan yaşılıarın ağır sakatlıktan tamamen iyileşme olasılıklarının olumsuz tutumları olan yaşlılara göre \%44 daha fazla olduğu tespit edilmiştir (15-17). Ageism, aynı zamanda yaşlının toplumdan dışlanarak marjinalleşmesine ve yalnızlaşmasına yol açmakta bu durum bireyin yaşam kalitesi ve süresini de azaltmaktadır (1820). Chang ve arkadaşları (21) tarafından 2020'de gerçekleştirilen, 1969-2017 yılları arasında yapılmış 422 çalışmanın dahil edildiği sistematik derlemede, çalışmaların \%95,5'inde yapısal ve bireysel düzeyde yaşlı ayrımcılığının yaşııların sağlığını pek çok noktada olumsuz 
yönde etkilediği tespit edilmiştir. Sağlık hizmetlerine ve tedaviye azalmış erişim yapısal düzeyde; azalmış yaşam kalitesi ve sosyal ilişkiler, fiziksel, mental hastalık ve riskli sağlık davranışları sıklığında artış, bireysel düzeyde yaşçılıktan en sık etkilenen çıktılar olmuştur (21).

\section{COVID-19 pandemi sürecinin yaşlılara etkisi, yaşlı ayrımcılığı}

COVID-19, tıbbi, psikolojik ve finansal etkileriyle küresel çapta yıkıcı bir fenomene dönüşen bir halk sağlığı krizidir. COVID-19 salgını hem bireysel hem toplumsal düzeyde birçok farklı alanda tüm dünyayı etkilemiştir. COVID-19 salgınının getirdiği sağlık sorunları ve ekonomik sıkıntının yoğunluğu, toplumun bazı kesimlerinde diğerlerinden daha güçlü olmuştur. Mevcut eşitsizliklerin şiddetlenmesi, düşük gelirli bireyleri ve kentsel alanlarda ikamet edenleri en fazla etkilemiştir. Olumsuz etkiler, sağlığın sosyal belirleyicilerine dayanan kırılganlıklarla kesişerek, yaşlı yetişkinleri ve ekonomik açıdan dezavantajı popülasyonları olumsuz sonuçlar açısından özellikle yüksek risk altında bırakmıştır (22). COVID-19 salgını, kökleşmiş yaşçılığın, cinsiyetçiliğin ve ırkçılığın yaşlı üzerindeki zararlı etkilerini bir kez daha gündeme getirmiştir (23).

COVID-19 salgını, dünya çapında 2021 Mart itibariyle teyit edilmiş 125 milyon vaka ve neredeyse 2,8 milyon ölümle etkisini dünyada 223 ülke, bölge ve alanda şiddetli bir şekilde devam etmektedir (24). COVID-19 ölümlerinin büyük bir kısmı, yeme, banyo ve tuvalet gibi günlük yaşamın temel aktivitelerinde yardıma intiyaç duyan fiziksel ve bilişsel bozuklukları olan yaşlı yetişkinleri tedavi eden uzun süreli bakım tesislerinde meydana gelmiştir (22). Yaşlanma fenomeni mutlaka bir hastalığa neden olmamaktadır, ancak insan organizmasının strese dayanma kabiliyetini kademeli olarak azaltmaktadır ve bu nedenle COVID-19 virüsünün yaşlı insanlar üzerindeki etkileri oldukça belirgin olmuştur (25). Yaşlıları morbidite ve mortalite açısından yüksek riskli olarak tanımlayan bilgiler, "son derece savunmasız bir grup" olarak etiketlemek bazı grupların davranış modellerini farklı şekilde etkileyerek yaşılıarı travmatize edecek düzeye varan bir ayrımcılığı ortaya çıkarmıştır (26). Yaşı insanların homojen bir şekilde "risk altında" olarak sınıflandırıldığı ve bu riskin azaltılmasının aynı zamanda pandeminin yayılmasını sınırlamak için mevcut önlemlerin ana yaklaşımı olduğu ifadeleriyle oldukça yaygın karşılaşılmıştır. Bu şekilde ileri yaşın vurgulanması sadece yaşlı yetişkinler arasında endişeler uyandırmakla kalmaz, aynı zamanda diğer yaş grupları arasında yanlış güvenlik duygularına da yol açabilir (27). Kronolojik yaşın, grupların iç farklılıklarını görmezden gelerek, onları nesnel olarak tanımladığı varsayımı; kitlelerin yaş temelindeki ayrımcı tutumlarını körükleyerek pandemiye paralel bir yaşlı ayrımcılığı salgınının patlak vermesine sebep olmuştur $(28,29)$. Virüsle mücadele esnasında sağlık bakımında ve sokağa çıkış kısıtlaması uygulamalarında yaş temelli kararların alınması, medyada ve sağlık yetkilileri açıklamalarında 'yaşlı' vurgusunun tekrarlaması, sosyal medyada yaşlı bireylere yönelik ötekileştirme/siber zorbalık/stigmatizasyonun artışı tüm toplumlarda yaşanan problemlerdir (30).

Pandemiler, ani ve aşırı yüklenmeye bağlı sağlık sistemlerinin cevap verebilme kapasitelerini aşarak ulusal ve küresel boyutlarda krizlere dönüşebilir. Talebin arttığı durumlarda kıt kaynakların tahsisinde (özellikle yoğun bakım yatağı ve ventilatör desteğine erişim vb.) sağ kalımı daha yüksek gruplara öncelik tanınması gibi faydacı yaklaşımlar benimsenebilir (31). COVID-19 pandemisi sürecinde, Amerika Birleşik Devletleri $(A B D)$ ve İtalya örneklerinde daha sık gördüğümüz, özellikle yaşlılara ve örselenebilir/ etkilenebilir gruplara yönelik tedaviye hiç başlamama ya da başlanmış tedavileri yarıda kesme şeklinde alınan kararlar ve yaklaşımlar, tedavinin önceliği konusunda doğrudan ya da dolaylı yaşa dayalı ayrımcı tutumlar bu süreçte etik açıdan oldukça eleştirilmiştir (31-33). Bu tarz kararların sadece kronolojik yaş temelinde alınması yaşlıların özerkliklerine ve yaşam haklarına zarar vermekle birlikte yaşlıların 'harcanabilir' olduğu düşüncesinin kurumsallaşmasına sebep olması açısından tehlikelidir (34).

Ülkeler arasında farklılık göstermekle birlikte çoğunlukla yaş temelinde uygulanan sokağa çıkış kısıtlamaları, bu tür önlemlerin iletilme şekli ve olumsuz yaş kalıplarını güçlendirip destekleme durumuna bağlı olarak çifte tuzak yaratmaktadır (30). Birincisi, toplumun yaşlı yetişkinlere intiyaç duymadığı ve bu süre zarfında kendilerini tecrit ederlerse onları kimsenin özlemeyeceği inancını oluşturarak yaşıların topluma katılımlarının önemini reddetmektedir $(30,35)$. İkincisi, genç nüfusu sorumluluktan kurtararak, gençlerin etkilenmediği, yenilmez olduğu ve 
sınırlandırmada oynayacak bir rolü olmadığı yanılsamasını yaratarak pandeminin yalnızca yaşlı yetişkinleri etkilediği tasviri virüsün toplumda daha hızlı yayılmasına sebep olmaktadır (30). Pandemi ilanının üzerinden çok uzun zaman geçmemişken, yüksek riskli Avrupa ülkelerinde bulunduktan sonra Japonya'daki partilere katılan gençler ve ABD'de bahar tatilinde tedbirsiz davranan öğrenciler bu noktada eleştirilmiş; Kuzey İtalya'daki kırmızı bölgeden virüsün daha az yaygın olduğu Güney İtalya'ya taşınmasında benzer şekilde gençlerin aktif rol oynadığı düşünülmektedir (36-38).

Pandemi sürecinde dünyada birçok ülkede, politik ve medyatik kişiler söylemlerinde 'yaşlı vurgusu' yaparak yaşlı ayrımcılığına zemin hazırlayan bir ortamın oluşmasına katkıda bulunmuşlardır (39). Teksas eyaleti vali yardımcısı 69 yaşındaki Dan Patrick'in yaşlı Amerikalılardan, 'Çocuklarının ve torunlarının iyiliği için kendilerini feda etmelerini ve böylece ekonomik vatanseverlik yapmaları gerektiği" açıklaması en bilinen örneklerindendir (40). Ana akım medyada benzer şekilde sıkça 'yaş vurgusu' yapıldığı görülmüştür. Günlük korona virüsü vaka ve ölüm bilgilerini paylaşmak için yapılan açıklamalarda özellikle yaşlı ölüm sayılarının verilmesi, yoğun bakım yatışlarındaki yaşı yüzdelerinin altının çizilmesi gibi vurguların kullanımı geriatri alanında çalışan profesyonellerin müdahalesiyle azalmıştır. Salgın sürecinin başlarında yerel yönetimlerin yaşlıların şehir merkezlerinde toplu vakit geçirdikleri alanlardan bankları kaldırması, zabıtaların yasaklara uymayan yaşılıara zor kullanması ve benzer şekilde yasaklara uymayan yaşlılara yönelik halktan bazı kesimlerin olumsuz tepkilerinin ana akım ve sosyal medyada yer alması salgının merkezine sadece 'yaşlı'yı koymak açısından tehlike arz etmiştir (39).

Pandemi sürecinde sosyal mesafe ve selfizolasyon önlemleri nedeniyle aile, arkadaşlar ve diğer insanlarla bağlantı kurmak için yararlı bir araç olan sosyal medya aynı zamanda yaşlı yetişkinlere yönelik antagonistik stereotipleri, önyargıları ve ayrımcılığı ifade etmek amacıyla da sıklıkla kullanılmıştır. Sosyal medyada, COVID-19 "Boomer Doomer", "Senior Deleter", "Elder Repeller" ve "Boomer Remover" gibi birçoğu yaşlı yetişkinlere ait farklı isimlerle anılmaktadır (41). Twitter'da \#BoomerRemover hashtag'ini kullanan $Z$ ve $Y$ kuşağı tarafından, virüsün yaşlı yetişkinleri hedef alarak nüfus kontrolü yaptığı ve yaşsılara ayrılan kamu harcamalarını azaltmaya yardım ettiği için öven kamuoyu tartışması Mart 2020'de tüm dünyada trend olmuştur $(29,41)$. Pandemi ilanının hemen ardından, 12 Mart-21 Mart 2020 tarihleri arasında atılan tweetlerin incelendiği bir çalışmada; analiz edilen tweetlerin neredeyse dörtte biri, yaşlı yetişkinlere yönelik yaşa veya potansiyel olarak saldırgan içeriğe sahip olduğu tespit edilmiştir (42). Gelecekte, bu yaş bölünmesi ve yaşlı yetişkinlerin ve yaşlanmanın olumsuz tasviri, mevcut pandemi bağlamında yaşıılık ve yaşlanmayla ilgili olumsuz mesajları da içselleştirdiklerinden gençlerin yaşlanma sürecini de etkilemesi muhtemeldir (43).

İsrail'de 50 yaş ve üzeri yetişkinlerin ulusal olarak temsil edildiği 1093 kişide yapılan kesitsel nitelikli araştırmada katılımcıların COVID-19 pandemisi sırasında yaş ayrımcılığına ilişkin algıları değerlendirilmiştir. Çalışmaya göre, kadınlar, öznel sağlık algısı kötü olanlar, yüksek ölüm kaygısı bildirenler ve sağlık hizmetlerinde yaşa dayalı ayrımcılığa uğradığını bildirenler anlamlı olarak yaşlıları daha savunmasız olarak algılamaktadırlar (44). Pandemi öncesi, Helsinki yaşlanma çalışmasına katılan 75-104 yaş arası katılımcıların \%21'i yaşlılara toplumda kötü muamele edildiğini düşündüğü belirlenmiştir (45).

COVID-19 pandemisi, dünyada karışık, sürekli gelişen ve değişen bir durum ortaya çıkarmıştır (46). Yaşları ne olursa olsun, tüm bireylerin günlük hayatlarını benzeri görülmemiş şekillerde etkileyen ve etkilemeye de devam eden örseleyici bir travma yaşatmaktadır (30). Ancak dezavantajlı ve özellikle toplumsal eşitsizlikleri derinden hisseden gruplar için travmanın şiddeti artmaktadır. Bireyin salgınla kurduğu ilişki dünya haritasındaki yerine, içinde bulunduğu ülkedeki vatandaşlık durumuna, yaşadığı şehrin mekânındaki konumuna, yaptığı işe, yaşına, sınıfına, cinsiyetine ve etnik kökenine göre şekillenmektedir. Bir diğer ifade ile sağlığın sosyal belirleyicileri bireyin salgındaki durumunu belirlemektedir (47). Özellikle salgının en fazla risklere maruz bıraktığı yaşlı nüfus bu süreçte hem biyolojik ve toplumsal hem de psikolojik olarak mücadele vermektedir ve toplumdan dışlanma tehlikesiyle karşı karşıyadır $(48,49)$. COVID-19 gibi küresel çaptaki bir krizde en yüksek risk teşkil eden gruplar; kayıt dışı ekonomiye bağlı çalışanlar, sosyal hizmetlere ve politikalara sınırlı erişime sahip olanlar veya erişime sahip olmayanlar, uyum sağlama ve başa çıkma konusunda yetersiz kapasiteye sahip 
olanlar, teknolojiye sınırlı erişimi olan veya hiç erişimi bulunmayanlar olarak belirtilmektedir (49).

Yaşıılar, sağlık hizmetlerine erişimi kriz dışı zamanlarda da yetersiz olması, bakım intiyacı, verilen bilgileri/mesajları anlayamama, talimatları takip etmede zorlanma ve bakım tesislerinde yaşamaları nedeniyle pandeminin en kırılgan grubunu oluşturmaktalar (49). Bu dönemde sağlık sistemleri COVID-19 vakalarını yönetmeye odaklanmıştır, bu da diğer sağlık gereksinimlerinin ertelenmesi anlamına gelmektedir. Düzenli muayeneler, acil olmayan hizmet sağlayıcı ziyaretler ve elektif prosedürler iptal edilerek yaşı hastaların sağlık durumunun kötüleşmesi açısından daha yüksek risk altına sokulmuştur (23).

Yaşlı çalışanlar, işyerinde yaş ayrımcılığı riski altındadır ve olmaya devam edecektir. Yaşlı işçiler, eğitim ve ilerleme fırsatlarında önyargı yaşarlar ve daha yüksek maaşlar ve sağlık sigortası maliyetleri göz önüne alındığında, genellikle erken emekli olma baskısı yaşarlar. Bu durum pandemi döneminde çok daha şiddetli yaşanmıştır, ekonomik kriz içinde olan işletmeler önce yaşlı çalışanları gözden çıkarmışlardır. Yaşlanmayla birlikte emeklilik sürecinin başlaması ve takiben gelir düzeyinin azalmasıyla yaşılık döneminde bazı yaşlıların çalışmaya devam etmelerine yol açmaktadır. Pandemi sürecinde gelen yasaklar nedeni ile çalışamayan yaşlılar da ciddi ekonomik sıkıntılar yaşamıştır (23). ABD'de 65 yaş üzeri çalışanlardan evden çalışabilenler diğer yaş gruplarına göre daha az olduğu belirtilmektedir. Yaşlı bireylerin bir kısmının çalıştığı iş, işyerinde ve manuel yapılması gereken işler olması nedeni ile ekonomik kayıpları olduğu vurgulanmaktadır. Ayrıca, tele çalışma fırsat veya olanaklarının olmaması, fiziksel çalışma ortamındaki sağlık ve güvenlik endişeleri veya gelecekteki yaş ayrımcılığına ilişkin beklentiler nedeni ile yaşlı yetişkinlerin bir kısmı erken ve planlanmamış emeklilik kararı almışlardır, bu durum da anksiyete ve depresyona neden olabilmektedir (26).

Yaşlılık, genel olarak uyum sağlama ve başa çıkma yeteneklerinde azalma ile karakterize bir dönemdir (49). Türkiye'de her beş yaşlıdan biri tek başına yaşamaktadır (51). Ülkemizde 21 Mart 2020'den beri devam eden kısıtlamalar sürecinde özellikle yalnız yaşayan yaşıların ilaç, gıda temizlik malzemeleri gibi temel gereksinimlerinin karşılanmasında artan bir şekilde başkalarına bağımlı hale gelmişlerdir. Rutin sağlık ve sosyal hizmetlere erişimi sınırlanan yaşlıların ev içi inmal, istismar ve şiddete uğrama riski artmakta ve erken tespit ve önlemlerin alınması sekteye uğramaktadır. Pandemi sürecinde, kişisel bakım, ilaç yönetimi ve beslenme ile ilgili bu aksaklıklar, uzun vadede yaşlı bireyin sağlığının bozulmasına ve daha fazla destekleyici hizmetlere intiyaç duyulmasına yol açacaktır. Ailesi ve çocuklarıyla birlikte yaşayan yaşlılar özellikle okulların kapanmasıyla birlikte torun bakımı gibi hane içi görevlerde daha sık yer almışlardır. Bu durum enfekte olma risklerini arttırmıştır (52).

Uzun süreli bakım tesisleri hem sakinlerinin ileri yaşları hem de sık görülen kronik altta yatan sağlık koşulları ve sağlık personeli kaynaklı bulaşlar nedeniyle, COVID-19 kaynaklı ciddi sonuçlar için yüksek riskli ortamlardır (53). Salgının erken dönemlerinde beş Avrupa ülkesinden gelen veriler bakım evi kaynaklı ölümlerin \%42-\%57 arasında değiştiği izlenmektedir (54). Ülkemizde 7 Mayıs 2020'de Aile, Çalışma ve Sosyal Hizmetler Bakanlığı tarafından bakımevlerinde bildirilen mortalite hızı \%4'tür (55). Ülkelerin demografileri, sağlık sektörünün gelişimi, kapasitesi ve erişim olanakları, virüsle mücadele stratejileri ve bakımevi sayısı ve doluluk oranları ölüm hızının belirleyicisi olmuştur (56).

Pandemi gibi kriz anlarında teknoloji kullanımı daha fazla önem kazanmaktadır. Yaşılıarın pandemi sırasında fiziksel ve zihinsel olarak sağlıklı kalabilmeleri ve hastalanmaları durumunda ne yapmaları gerektiği konusunda açık mesajlara ve kaynaklara sahip olmalarını sağlamak için doğru bilgilere erişimleri kritik öneme sahiptir (57). Türkiye İstatistik Kurumu, 2019 hane halkı bilişim teknolojileri kullanım araştırmasına göre yıllar içerisinde 65-74 yaş grubundaki internet kullanan birey sayısı arttı ancak buna rağmen yaşlıların \%56'sının hanesinde internet bağlantısı bulunmamaktadır $(51,58,59)$. Ne yazık ki ülkemizde yaşı yetişkinler arasında modern bilgi ve iletişim teknolojilerinin kullanımını teşvik eden herhangi bir girişim veya düzenleme bulunmamaktadır (60).

Bir yandan yaşılıarın gözden çıkarılabilir grup olması yaklaşımı, bir yandan da yardımseverlik çabalarının sergilenmesi nedeni ile pandemi sürecinde kararsız bir yaş ayrımcılığı yaşandığı bahsi geçmektedir. Yaşlı yetişkinlere yönelik görünüşte olumlu yardım davranışlarının bir 
başka istenmeyen olumsuz sonucu, tüm yaşlı yetişkinlerin bağımlı, kırılgan, hastalıklı, zayıf ve toplum üzerinde bir yük olduğu gibi pre-pandemik olumsuz klişelerin sürdürülmesidir. Yardım edici davranışlar bazen fazla koruyucu olabilir ve yaşlı yetişkinlerde çaresiz ve bağımlı oldukları (hayırsever yaş ayrımcılığı) algısını oluşturabilir; bu da onların benlik saygısı ve iyilik hali üzerinde olumsuz bir etkiye sahip olabilir (61).

\section{Pandemi sürecinde yaşlıya yönelik iyi uygulamalar ve müdahaleler}

Pandemi süreci ilerledikçe meşruiyet ilkesi göz önünde bulundurularak kırılgan ve riskli grupların şartlarının iyileştirilmesi ve öncelik tanınması yönünde küresel ve ulusal düzeylerde olumlu adımlar da atılmaktadır. DSÖ, küresel düzeyde aşılama uygulamaları başlamadan önce özellikle kıt kaynakların tahsisine yönelik ülkelere üç farklı hastalık epidemiyolojik yayılım süreci ve aşı tedarik oranlarını içeren faklı senaryolar üzerinden yol haritası niteliğinde rehber hazırlamıştır. Hastalığa maruz kalma, hastalığı ağır geçirme ve bulaştırma riskleri ile hastalığın toplumsal yaşamın işleyişi üzerindeki olumsuz etkisi değerlendirilerek gruplandırmalar yapılması, öncelikli grupların sırayla aşılanması; birinci gruptakiler için yeterince aşı yoksa ikinci gruba geçilmemesi önerilmektedir. Toplum katıımı ve etkili iletişimin önemi, sürece dair şeffaf bilgilendirmenin değeri vurgulanarak atılacak her adımda meşruiyet ilkesinin göz önünde bulundurulması tavsiye edilmektedir (61).

COVID-19 salgınının, politikalar, sistemler ve hizmetlerdeki vurguladığı eksiklikler hazırlanan eylem planlarında göz önünde bulundurulmaktadır. Dünya Sağlık Örgütünün 2021-2030 yıllarını kapsayan 'Sağlıklı Yaşlanma Dekadı', COVID-19 salgını sırasında hem de sonrasında yaşlı insanların, ailelerinin ve toplulukların yaşamlarını iyileştirmek için çok paydaşı bir şekilde ele alınarak iyileştirilmesi hedeflenmektedir (62).

Kuşaklar arası etkileşimin artırılması yaşı ayrımcılığını azaltmaya yönelik en önemli müdahale noktasıdır (11). COVID-19 pandemisi süresince yüksek morbidite ve mortalite riski ve sokağa çıkış kısıtlamaları nedeniyle özellikle tek başına yaşayan yaşlıların temel intiyaçlarını karşılayamayarak birine bağımlı olmaları sürecin uzamasıyla da işlevsizlik duygusunu ve özerklik kaybını pekiştirmektedir (52). Bu süreçte yerel yönetimler, kamu çalışanları, sivil toplum kuruluşları (STK) ve gönüllüler üzerinden yürütülen gönüllü toplum faaliyetleriyle yaşlıların gıda ve ilaç gibi temel intiyaçlarının sağlanması, sosyal etkileşimin sürdürülmesi ve ulaşım intiyaçlarının giderilmesi faaliyetleri yürütülmüştür. Polonya, Lodz (Łódź) kentinde yürütülen toplum gönüllüğü faaliyetleriyle yaşlıların sağlıklarını riske atmadan evde kalması sağlanarak potansiyel hastane masraflarının engellendiği tahmin edilmektedir (63). Ulusal düzeyde İngiltere, "National Health Service (NHS) Gönüllüleri", "Royal Voluntary Service", GoodSAM App. ve ülkemizde yürütülen "Vefa Sosyal Destek Grupları" uzun süren izolasyon dönemlerinde yaşlı nüfusun temel intiyaçlarının karşılanmasında multidisipliner bir ekip çalışması yürütmektedirler. ABD'de "Zoomers to Boomers" gibi çok sayıda kuşaklar arası programlar ortaya çıktığı belirtilmektedir (23). Özellikle kriz zamanlarında kuşaklar arası etkileşimin sürdürülmesi olumsuz stereotiplerin azaltılması ve empati duygusunun karşılıklı gelişmesi açısından uygun bir zemin yaratmakta bu durum gençlerin kendi öznel yaşlanma deneyimlerinin olumsuz etkilenmemesi açısından önem taşımaktadır (43).

COVID-19 salgını, dijital eşitsizliklerin, hem maruz kalmanın sağlıkla ilgili etkilerine hem de virüsün yayılmasına ve pandeminin sosyoekonomik sonuçlarına yönelik önemli bir savunmasızlık faktörü haline geldiği ilk büyük ölçekli olayı temsil etmektedir. İzolasyon gittikçe daha şiddetli hale geldikçe, sanal alanlar, dijital medya ve kitle iletişim araçları sadece bilgi yayma aracı olarak değil, aynı zamanda potansiyel olarak sosyal etkileşimlerin gerçekleşmesi için geriye kalan tek araç olarak eşi görülmemiş bir yer almaktadır (64). Özellikle teknoloji kullanımı sınırlı olan yaşılıarın bu bağlamda karşılaştıkları zorluklar artmıştır. Kasım 2020'de Çin'de "yaşlıların akıllı teknolojiyi kullanırken karşılaşacakları zorlukları çözmek" ve "yaşlıların dijital gelişmelerin kazanımlarına ortak olmasını sağlamak" amacıyla ulusal düzeyde eylem planı başlatılmış; pandemi sonrası giderek artan uygulama tabanlı günlük hayata yaşlıların uyumunu arttırma ve özerkliklerinin korunması hedeflenmiştir (65).

COVID-19 salgınından kaynaklanan zorluklara rağmen, bu krizden yaşlı yetişkinlerin yaşamlarını iyileştirme fırsatları doğabilir. Bunlar, teknoloji, aile ve kuşaklar arası ilişkiler yoluyla artan bağlantı ve sosyal izolasyonu azaltarak, öz 
bakımı ve yönetimi artırarak, sağlık ve sosyal hizmetlerde gelişmiş ve iyileştirilmiş kılavuzlar hazırlanarak gerçekleştirilmeye başlamıştır. Ayrıca yaşlanma alanında uzmanlaşmış profesyonellerin eksikliğinin, genellikle yaşılıarın özel sorunlarına duyarsız sağlık sistemlerinin yaşlılara yönelik hazırlıklı olmadığının farkına varılması sağlanmıştır (23). Bu süreçte yaşlı yetişkinlerin teknoloji becerilerini öğrenmeye hevesli olduklarını ve intiyaç duyduklarında bu becerileri kullanmaya özellikle motive oldukları görülmüştür. Pandemi sürecinde, yiyecek siparişi vermek, çevrimiçi egzersiz dersleri almak ve aile üyeleri ve sağlık hizmeti sağlayıcıları ile konuşmak amacı ile daha fazla yaşlı birey teknoloji ile yakınlaşmıştır. Yaşlı yetişkinlerin teknolojiyi daha rahat kullanmaları ve toplum ve sağlık hizmeti sağlayıcılarının uzaktan programlama sunması sağlanmıştır. Sosyal mesafe önlemleri kaldırıldıktan sonra bile yaşlı kişilerin çevrimiçi bağlantı kurması ve pek çok çevrimiçi hizmet alabilmesi açısından gelişmelere, pandemi itici güç olmuştur (23).

\section{SONUC}

Başta sağlık ve sosyal olmak üzere hizmet sunucular, politika yapıcılar tarafından şu gerçeklerin bir kez daha farkına varılması sağlanmıştır: Psikolojik performans, sosyal intiyaçlar ve kişilik özelliklerindeki bireyler arası değişkenliği ve somatik işlevler, temel sağlık ve tıbbi göstergeleri (algılanan sağlık, bilişsel sağlık ve günlük yaşam aktiviteleri ve bunun gibi pek çoğu) açısından 65 yaş ve üstü yaşlılar heterojen bir gruptur. Kronolojik yaş; davranış, intiyaç, performans, işlev kaybı, hastalık ve komorbiditeyi doğru bir şekilde tahmin etmek için son derece zayıf bir göstergedir. Yoğun bakım ve diğer tıbbi bakım türleri için yaş sınırları uygunsuzdur ve etik değildir; tıbbi bakım ve sınırlamaları ile ilgili kararlarda her hastanın sağlığı ve işleyişi dikkatle değerlendirilmelidir. Bu şekilde, bireylerin haklarına saygı duyulurken olabildiğince çok insan hayatı kurtarılabilir.

COVID-19 pandemisi sürecinde daha önce yaşanmamış pek çok deneyimle karşı karşıya kalınmış ve bu dönemde yaşlı bireyler en çok tartışılan grup haline gelmiştir. Yaşlı bireyler için zorlu geçen günlerde özellikle bir kriz anında toplumumuzun temel değerlerini korumak ve bireylerin, özellikle en zayıfların haklarını korumanın önemi kavranmıştır.

Çıkar çatışması: Yazarlar çıkar çatışması beyan etmemişlerdir.

\section{Kaynakça}

1. Deshpande J. V, Kochar S. C, Singh H. Aspects of positive ageing. Journal of Applied Probability 1986; 748-58.

2. Angus J, Reeve P. Ageism: A threat to "aging well" in the 21st century. Journal of Applied Gerontology 2006; 25 (2): 137-52.

3. Officer A, de la Fuente-Núñez, V. A global campaign to combat ageism. Bulletin of the World Health Organization 2018; 96 (4): 295.

4. Çilingiroğlu N, Demirel S. Yaşlılık. "yaşlı ayrımcılığı." Türk Geriatri Dergisi 2004; 7 (4): 225-30.

5. Ayalon L, Dolberg P, Mikulionienè S. A systematic review of existing ageism scales. Ageing research reviews 2019; 54: 100919.

6. Agesim- berkeley.edu. Robinson B. Ageism. University of California at Berkeley [updated 1994; cited 3 Apr 2005]. Available from: http://socrates.berkeley.edu/ aging/ModuleAgeism.htm

7. Palmore, E. B. Ageism: Negative and Pozitive. 2. Baskı New York: Springer Publishing Company; $1999: 1-6$.

8. Palmore E B Research note: ageism in Canada and the United States. Journal of cross-cultural gerontology 2004; 19 (1): 41-46.

9. Ayalon L. Perceived age, gender, and racial/ethnic discrimination in Europe: Results from the European social survey. Educational Gerontology 2014; 40 (7): 499-517.

10. Peterson L, Ralston M. Valued elders or societal burden: Cross-national attitudes toward older adults. International Sociology 2017; 32 (6): 731-54.

11. Global Report On Ageism-who.int. [updated 18 Mar 2021; cited 21 Mar 2021]. Available from: https://www.who.int/publications/i/item/9789240020504

12. Marques S, Mariano J, Mendonça J. Determinants of ageism against older adults: a systematic review. International journal of environmental research and public health 2020; 17 (7): 2560.

13. Ulukan U. Türkiye'de Demografik Dönüşüm ve Yaşlı İşçiler. Fiscaoeconomia 2020; 4 (1): 94-110. 
14. Walker A. Commentary: The emergence and application of active aging in Europe. Journal of aging \& social policy 2008; 21 (1): 75-93.

15. Lamont R A, Swift $H$ J, Abrams D. A review and meta-analysis of age-based stereotype threat: negative stereotypes, not facts, do the damage. Psychology and aging 2015; 30 (1): 180.

16. Wurm S, Benyamini Y. Optimism buffers the detrimental effect of negative self-perceptions of ageing on physical and mental health. Psychology \& Health 2014; 29 (7): 832-48.

17. Levy B R, Slade M D, Murphy T E, Gill T M. Association between positive age stereotypes and recovery from disability in older persons. Jama 2012; 308 (19): 1972-73.

18. Vitman A, lecovich E, Alfasi N. Ageism and social integration of older adults in their neighborhoods in Israel. The Gerontologist 2014; 54 (2): 177-89.

19. McHugh K E. Three faces of ageism: society, image and place. Ageing \& Society 2003;23(2):165-85.

20. Levy B R, Slade M D, Kunkel S R, Kasl S V. Longevity increased by positive self-perceptions of aging. Journal of personality and social psychology 2002; 83 (2): 261.

21. Chang E S, Kannoth S, Levy S, Wang S Y, Lee J E, Levy B R. Global reach of ageism on older persons' health: A systematic review. PloS one 2020; 15 (1): e0220857.

22. Miller E A. Protecting and improving the lives of older adults in the COVID-19 Era. Journal of Aging \& Social Policy 2020; 32 (4-5): 297-309.

23. Morrow-Howell N, Galucia N, Swinford E. Recovering from the COVID-19 pandemic: A focus on older adults. Journal of aging \& social policy 2020; 32 (4-5): 526-35.

24. Coronavirus disease (COVID-19) pandemic- who.int. [updated 27 Mar 2021; cited 28 Mar 2021]. Available from:https://www.who.int/emergencies/diseases/novel-coronavirus-2019 Erişim:28.03.2021

25. Clarfield A M, Jotkowitz A. Age, ageing, ageism and "age-itation" in the Age of COVID-19: rights and obligations relating to older persons in Israel as observed through the lens of medical ethics. Israel journal of health policy research 2020; 9 (1): 1-13.

26. Monahan C, Macdonald J, Lytle A, Apriceno M, Levy S R. COVID-19 and ageism: How positive and negative responses impact older adults and society. American Psychologist. 2020.

27. Ehni H J, Wahl H W. Six propositions against ageism in the COVID-19 pandemic. Journal of Aging \& Social Policy 2020; 32 (4-5): 515-25.

28. Lichtenstein B. From "coffin dodger" to "boomer remover": Outbreaks of ageism in three countries with divergent approaches to coronavirus control. The Journals of Gerontology: Series B 2021;76(4):e206-e212.

29. Morrow-Howell N, Galucia N, Swinford E. Recovering from the COVID-19 pandemic: A focus on older adults. Journal of aging \& social policy 2020;32(4-5):526-35.

30. Previtali F, Allen L D, Varlamova M. Not only virus spread: The diffusion of ageism during the outbreak of COVID-19. Journal of Aging \& Social Policy 2020; 32 (4-5): 506-14.

31. Büken, N Ö. COVID 19 pandemisi ve etik konular. Sağlık ve Toplum 2020;7(Suppl COVID-19 Özel Sayısı): 15.

32. British Medical Association (BMA)-bma.org.uk. London, UK: COVID-19-Ethical issues. A guidance note [updated 13 Mar 2020; cited 28 Mar 2021]. Available from: https://www.bma.org.uk/media/2226/bma-covid19-ethics-guidance.pdf.

33. Cesari M, Proietti M. COVID-19 in Italy: ageism and decision making in a pandemic. Journal of the American Medical Directors Association 2020;21(5):576-77.

34. Leaders speak out about their concerns regarding older people in the context of COVID-19-who.int. [updated 12 Jun 2020; cited 01 Sep 2020]. Available from:https://www.who.int/news-room/featurestories/detail/leaders-speak-out-older-people-covid-19

35. Many parts of America have already decided to sacrifice the elderly- washingtonpost.com. Coughlin J, L. Yoquinto. The Washington Post [updated 13 Apr 2020; cited 01 Sep 2020].

Available from:https://www.washingtonpost.com/outlook/2020/04/13/many-parts-america-have-alreadydecided-sacrifice-elderly/

36. If I get corona, I get corona: Coronavirus pandemic doesn't slow spring breakers' party- usatoday.com. Miller W R. The US Today [updated 19 Mar 2020; cited 01 Sep 2020].

Available from:https://eu.usatoday.com/story/travel/destinations/2020/03/19/spring-break-beaches-floridalook-packed-despite-coronavirus-spread/2873248001/ 
37. Officials plead with young people to stop partying during pandemic-asahi.com. Takashima M. The Asahi Shimbun [updated 31 Mar 2020; cited 06 Jun 2020]. Available from:http://www.asahi.com/ajw/articles/13260124

38. Al Sud i Danni Collaterali Dell'emergenza. Sindaci Spiazzati Dai Ritorni Rorzati. La Stampa- lastampa.it. Di Marino A. La Stampa [updated 25 Feb 2020; cited 06 Jun 2020]. Available from:https://www.lastampa.it/cronaca/2020/02/25/news/al-sud-i-danni-collaterali-dell-emergenza-sindacispiazzati-dai-ritorni-forzati-1.38512545

39. Altın Z. Covid-19 Pandemisinde Yaşlılar. Tepecik Eğit. ve Araşt. Hast. Dergisi 2020; 30: 49-57.

40. Older people would rather die than let Covid-19 harm US economy- theguardian.com. Texas, USA Beckett L. the Guardian. [updated 24 Mar 2020; cited 26 Oct 2020]. Available from:

https://www.theguardian.com/world/2020/mar/24/older-people-would-rather-die-than-let-covid-19-lockdownharm-us-economy-texas-official-dan-patrick

41. Meisner B A. Are you OK, Boomer? Intensification of ageism and intergenerational tensions on social media amid COVID-19. Leisure Sciences 2020;1-6.

42. Jimenez-Sotomayor M R, Gomez-Moreno C, Soto-Perez-de-Celis E. Coronavirus, ageism, and Twitter: An evaluation of tweets about older adults and COVID-19. Journal of the American Geriatrics Society 2020; 68 (8): 1661-65.

43. Ayalon L, Chasteen A, Diehl M, et al. Aging in times of the COVID-19 pandemic: Avoiding ageism and fostering intergenerational solidarity. The Journals of Gerontology: Series B 2020.

44. Cohn-Schwartz E, Ayalon L. Societal views of older adults as vulnerable and a burden to society during the COVID-19 outbreak: Results from an Israeli nationally representative sample. The Journals of Gerontology: Series B 2020.

45. Knuutila M, Lehti T E, Karppinen H, Kautiainen H, Strandberg T E, Pitkala K H. Associations of perceived poor societal treatment among the oldest-old. Archives of Gerontology and Geriatrics 2021; 93: 104318.

46. Canatan K. Kriz Zamanlarında Sosyal Mesafe. Adam Akademi Sosyal Bilimler Dergisi 2020; 10 (1): 1-18.

47. COVID-19 Pandemisi ve Sağıı̆ın Sosyal Bileşenleri, Türk Toraks Derneği COVID-19 E-Kitapları Serisi; 2020: 5-24.

48. D'cruz M, Banerjee D. An invisible human rights crisis: The marginalization of older adults during the COVID19 pandemic-An advocacy review. Psychiatry research 2020; 113369.

49. Women, U. N. COVID-19: How to Include Marginalized and Vulnerable People in Risk Communication and Community Engagement; 2020.

50. Ciafone A, McGeehan Muchmore D. Old Age and Radical History: Editors' Introduction 2021; $1: 12$.

51. TÜIK, İstatistiklerle Yaşlılar, 2019-tuik.gov.tr. [updated 18 Mar 2020; cited 02 Apr 2021]. Available from:https://data.tuik.gov.tr/Bulten/Index?p=Istatistiklerle-Yaslilar-2019-33712.

52. DEMIR S A. SALGIN SÜRECINDE YAŞLI NÜFUS, SOSYAL DIŞLANMA VE YAŞ AYRIMCILIĞI. Süleyman Demirel Üniversitesi Sosyal Bilimler Enstitüsü Dergisi 2020; 38: 186-201.

53. McMichael T M, Currie D W, Clark S, et al. Epidemiology of Covid-19 in a long-term care facility in King County, Washington. New England Journal of Medicine 2020;382(21):2005-11.

54. Comas-Herrera A, Zalakaín J, Litwin C, Hsu A T, Lane N, Fernández J L. Mortality associated with COVID-19 outbreaks in care homes: early international evidence. Article in LTCcovid. org, International Long-Term Care Policy Network 2020;CPEC-LSE:26.

55. Huzurevinde virüsten ölüm oranı Kanada'da yüzde 71, Türkiye'de yüzde 4- yenisafak.com [updated 07 May 2020; cited 04 Apr 2021]. Available from: https://www.yenisafak.com/koronavirus/huzurevinde-virusten-olum-orani-kanadada-yuzde-71-turkiyedeyuzde-4-3538428.

56. Serdar E K, ILHANLI H, Kahraman S Ö. COVID-19'un zayıf halkası: Yaşlı nüfus. Türk Coğrafya Dergisi 2020; 76: 33-44.

57. TANRIVERDI G, GÜRSOY M Y G, KAYMAK G Ö. Halk Sağlığı Hemşireliği Yaklaşımıyla COVID-19 Pandemisi. Halk Sağlığı Hemşireliği Dergisi 2020; 2 (2): 126-42.

58. Hanehalkı Bilişim Teknolojileri Kullanım Araştırması, 2014-tuik.gov.tr. [updated 22 Aug 2014; cited 06 Jun 2020]. Available from:https://data.tuik.gov.tr/Bulten/Index?p=Hanehalki-Bilisim-Teknolojileri-(BT)-KullanimArastirmasi-2014-16198. 
59. Hanehalkı Bilişim Teknolojileri Kullanım Araştırması, 2019-tuik.gov.tr. [updated 27 Aug 2019; cited 06 Jun 2020]. Available from: https://data.tuik.gov.tr/Bulten/Index?p=Hanehalki-Bilisim-Teknolojileri-(BT)-KullanimArastirmasi-2019-30574.

60. Can H B. Olağanüstü Durumlarda Geliştirilen Sosyal Politikaların Dezavantajlı Gruplar Üzerindeki Etkisinin Sosyal Hizmet Perspektifinden Değerlendirilmesi: COVID-19 Pandemisi Türkiye Örneği. Sosyal Hizmet 2020;47.

61. Maxfield M, Pituch K A. COVID-19 worry, mental health indicators, and preparedness for future care needs across the adult lifespan. Aging \& mental health 2020;1-8.

62. UN Decade of Healthy Ageing-who.int. [updated 14 Dec 2020; cited 28 Feb 2021]. Available from: https://www.who.int/initiatives/decade-of-healthy-ageing

63. City Volunteering Service keeps older people safe in Łódź, Poland- who.int. [updated 5 Feb 2020; cited 28 Feb 2021].

Available from:https://www.who.int/news-room/feature-stories/detail/city-volunteering-service-keeps-olderpeople-safe-in-\%C5\%82\%C3\%B3d\%C5\%BA-Poland

64. Beaunoyer E, Dupéré S, Guitton M J. COVID-19 and digital inequalities: Reciprocal impacts and mitigation strategies. Computers in human behavior 2020;111:106424.

65. In Tech-Savvy China, Cash-Carrying Elderly Are Being Left Behind -sixthtone.com. Lianzhang W. [updated 25 Nov 2020; cited 8 Mar 2021].

Available from: http://www.sixthtone.com/news/1006499/in-tech-savvy-china\%2C-cash-carrying-elderly-arebeing-left-behind. 